\title{
Temporal and spatial dynamics of diatom (Bacillariophyceae) communities in a peatland area
}

\author{
Petra Thea MUTINOVÁa,b* Jana KULICHOVÁ ${ }^{b}$ \& Karl Inne UGLAND ${ }^{c}$ \\ ${ }^{a}$ Norwegian Institute for Water Research (NIVA), Gaustadalléen 21, 0349 Oslo, \\ Norway \\ ${ }^{b}$ Department of Botany, Faculty of Science, Charles University, \\ Benátská 2, 12801 Prague, Czech Republic \\ ${ }^{c}$ Marine Biology Research Group, Department of Biology, University of Oslo, \\ $\mathrm{Pb} 1066$ Blindern, 0316 Oslo, Norway
}

\begin{abstract}
This study was conducted to simultaneously investigate the spatial and temporal dynamics of diatom communities inhabiting two microhabitat types (Sphagnum periphyton and epipelon) in a peatland area of the Czech Republic. The changes in diatom community structure and corresponding diversity indices at both large (i.e., variation between sites) and small (i.e., variation between two microhabitats) scales were assessed through time. The results indicated clear spatial patterns at large, but not at small scale, and only limited seasonal dynamics in the diatom community. At the large scale, significant differences in diatom communities among sites were associated with both geographic position and environmental conditions ( $\mathrm{pH}$ and conductivity). A significant effect of microhabitat type was detectable within sampling sites; the relationship between other factors and species data was not important on a small scale. The results of this study showed that both diatom diversity and community structure are good indicators of ecological heterogeneity associated with relatively high spatial and/or environmental variability. However, subtle differences in environmental conditions are hardly detectable or hidden using traditional diatom species.
\end{abstract}

Diatoms / microhabitat / peatland / spatial dynamics / temporal dynamics

\section{INTRODUCTION}

The temporal and spatial dynamics of communities are important components of biodiversity. The focus on these aspects of communities has increased in recent years, because knowledge of biodiversity aids understanding of ecosystem functions and improves monitoring and restoration programs (Legendre et al., 2005). Peatlands are inhabited by specific protist communities, which play key roles in the nutrient and energy cycles of the habitat (Gilbert et al., 1998a, 1998b; Mitchell et al., 2003). The majority of existing research on this topic has considered testate amoebae (Arcellinida and Euglyphida; e.g. Lamentowicz \& Mitchell, 2005; Mieczan, 2007, 2009) and desmids (Desmidiales; e.g. Štěpánková et al., 2008; Št’astný, 2010; Neustupa et al., 2012; Svoboda et al., 2014). These two characteristic protist groups are dominant in peatlands, and they are frequently used in paleoecological studies

\footnotetext{
* Corresponding author: petra.mutinova@niva.no
} 
and peatland monitoring programs (Coesel, 2001, 2003; Mitchell et al., 2008). Diatoms (Bacillariophyceae) are also potential model organisms for biomonitoring (Dixit et al., 1992; Poulíčková et al., 2004; Charles et al., 2006; Kelly et al., 2012), and they are equally as important as testate amoebae and desmids in the peatland microbenthos. However, studies focusing on the community structure of diatoms in peatlands are relatively scarce and rather covered by those considering the entire microphytobenthos (Mataloni, 1999; Borics et al., 2003; Nováková, 2007; Tropea et al., 2007; Machová-Černá \& Neustupa, 2009).

Generally, freshwater microalgae are affected in space and time by prevailing environmental conditions, particularly $\mathrm{pH}$, conductivity, and nutrients (e.g. Mataloni, 1999; Potapova \& Charles, 2002; Poulíčková et al., 2004; Soininen, 2004; Soininen et al., 2004; Nováková, 2007; Stěpánková et al., 2008; Fránková et al., 2009; Machová-Černá \& Neustupa, 2009; Neustupa et al., 2013). The effects of random processes and biotic interactions, which are typically indirectly estimated, may also be important for community structure (Leibold et al., 2004; Svoboda et al., 2014). Seasonal dynamics have significant effects on the structure of planktonic communities, and this is commonly described by the PEG-model (Phytoplankton Ecology Group; Sommer et al., 1986, 2012). However, the microphytobenthos is more likely to be spatially structured, and geographic distance significantly affects microphytobenthos species composition at a large scale (e.g. Potapova \& Charles, 2002; Soininen, 2004; Soininen et al., 2004; Pals et al., 2006; Machová-Černá \& Neustupa, 2009; Veselá, 2009; Heino et al., 2010; Neustupa et al., 2012, 2013; Svoboda et al., 2014; Mutinová et al., 2016). Noticeable within site differences have been detected at a small scale, and these differences might be enhanced if two distinct microhabitat types (e.g., soft versus hard substrates or biologically active versus biologically inert substrates) are considered (Lim et al., 2001; Borics et al., 2003; Poulíčková et al., 2004; Soininen \& Eloranta, 2004; Potapova \& Charles, 2005; Townsend \& Gell, 2005; Veselá, 2009). Nevertheless, in most cases, the differences in the microphytobenthos at a large scale (i.e., between ecologically distinct sites) are usually more striking as compared to spatial variation within a single site (Soininen, 2004; Pals et al., 2006; Mutinová et al., 2016), and this could lead to the false assumption that the microhabitats have minor effects on the structure of their associated communities.

This study aimed to investigate the diversity of diatoms and to quantify the importance of temporal and spatial factors on the diatom community structure in a peatland area. Variation in the following response variables was statistically partitioned: time (seasonal and inter-annual environmental changes), space (distance between sampling sites and different types of microhabitats), and environment $(\mathrm{pH}$, conductivity, and temperature). In previous studies (Nováková, 2007; Neustupa et al., 2011), temporal dynamics have primarily been examined as seasonal changes in the community. We sampled for two successive years to study inter-annual or aperiodic fluctuations in diatom diversity and community structure that may be attributed to seasonal changes during a short-term investigation. The spatial dynamics of diatom communities were studied at two scales: among sampling sites (hereafter referred to as "large scale") and within sites (i.e., among microhabitats; hereafter referred to as "small scale"). We expected to find profound spatial dynamics and at least some detectable temporal changes in the diatom communities in peatland microhabitats. We hypothesized that dark shallow peatland pools undergo numerous, rapid changes in environmental factors, which would result in detectable temporal dynamics of microphytobenthic communities (as reported by Machová-Černá \& Neustupa (2009) and Neustupa et al. (2012) in relation to winter disturbances). 


\section{MATERIAL AND METHODS}

\section{Sampling and sample processing}

Samples were collected at six sites from two microhabitats in the peatland pools surrounding Mácha Lake (altitude $266 \mathrm{~m}$ a.s.1.) in the Czech Republic (Table 1). The samples were collected from May 2010 to March 2012, and collections were made during all four seasons (Supplementary Table 1, see doi/10.7872/crya/ v38.iss3.2017.Suppl.Mat.). During the winter months, an ice cover was carefully removed and replaced after sampling. This study design resulted in eight successive sampling events (Supplementary Table 1), so it was possible to detect both intraannual (i.e., seasonal) and inter-annual variability of the diatom communities.

Sites 1 and 2 were located in the lowland minerotrophic fen "U Klůčku". The other four sites were set in the adjacent peatland pools of the Swamp Nature Reserve and in the northern part of Mácha Lake. All sites were classified as lowland minerotrophic transitional bogs characterized by acidic and oligo-mesotrophic conditions (Neustupa et al., 2013). Environmental factors ( $\mathrm{pH}$ and conductivity) were measured in the field using a combined $\mathrm{pH} /$ conductometer WTW 340i (WTW $\mathrm{GmbH}$, Weilheim, Germany) in the immediate vicinity of sampled microhabitats. Mean temperatures for a period of 30 days prior to sampling were obtained from publicly available websites for the Prague Ruzyne Station that is located $63 \mathrm{~km}$ from the sampling area (http://www.vurv.cz/meteo/default.asp). A summary of the sampling sites and environmental conditions are shown in Table 1 and Supplementary Table 1 (see doi/10.7872/crya/v38.iss3.2017.Suppl.Mat.). The difference among sampling sites based on $\mathrm{pH}$ and conductivity values are illustrated in a scatter plot (Fig. 1).

Table 1. Overview of the sampling sites, corresponding environmental factors (mean \pm standard deviation), and species richness based on 300 cell counts. Species richness is also given separately for epipelon (EPI) and Sphagnum spp. periphyton (PERI) microhabitats

\begin{tabular}{|c|c|c|c|c|c|c|}
\hline \multirow{2}{*}{ Site } & \multirow{2}{*}{$G P S$} & \multirow{2}{*}{$p H$} & \multirow{2}{*}{$\begin{array}{c}\text { Conductivity } \\
{[\mu \mathrm{S} / \mathrm{cm}]}\end{array}$} & \multicolumn{3}{|c|}{ Species richness } \\
\hline & & & & $E P I$ & PERI & Total \\
\hline 1 & $50^{\circ} 34^{\prime} 39.4^{\prime \prime} \mathrm{N}, 1^{\circ} 39^{\prime} 46.0^{\prime \prime} \mathrm{E}$ & $6.7 \pm 0.3$ & $281 \pm 113$ & 27 & 30 & 35 \\
\hline 2 & $50^{\circ} 34^{\prime} 36.7^{\prime \prime} \mathrm{N}, 14^{\circ} 39^{\prime} 46.7^{\prime \prime} \mathrm{E}$ & $6.3 \pm 0.2$ & $383 \pm 113$ & 23 & 25 & 30 \\
\hline 3 & $50^{\circ} 34^{\prime} 33.0^{\prime \prime} \mathrm{N}, 14^{\circ} 40^{\prime} 15.5^{\prime \prime} \mathrm{E}$ & $5.0 \pm 0.4$ & $95 \pm 43$ & 32 & 26 & 40 \\
\hline 4 & $50^{\circ} 35^{\prime} 40.7^{\prime \prime} \mathrm{N}, 14^{\circ} 38^{\prime} 44.9^{\prime \prime} \mathrm{E}$ & $5.0 . \pm 0.6$ & $70 \pm 32$ & 21 & 17 & 24 \\
\hline 5 & $50^{\circ} 34^{\prime} 30.7^{\prime \prime} \mathrm{N}, 14^{\circ} 40^{\prime} 06.1^{\prime \prime} \mathrm{E}$ & $4.5 \pm 0.5$ & $104 \pm 37$ & 24 & 12 & 26 \\
\hline 6 & $50^{\circ} 35^{\prime} 43.1^{\prime \prime} \mathrm{N}, 1^{\circ} 38^{\prime} 36.8^{\prime \prime} \mathrm{E}$ & $4.0 \pm 0.2$ & $92 \pm 38$ & 8 & 9 & 10 \\
\hline
\end{tabular}

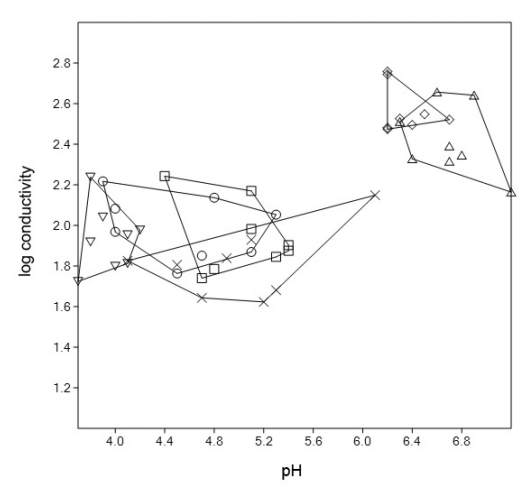

Fig. 1. Scatter plot illustrating the differences in environmental parameters among individual sites. Triangle $=$ site 1 , diamond $=$ site 2 , square $=$ site 3 , cross $=$ site 4 , circle $=$ site 5 , inverted triangle $=$ site 6 . 
Two types of microhabitats, epipelon (EPI) and Sphagnum spp. periphyton (PERI) were chosen. Epipelon microhabitat samples were carefully collected from an area of approximately $0.25 \mathrm{~m}^{2}$, but only the top surface layer of sediment was sampled to prevent mixing with the underlying sediment layer. Samples from the periphyton microhabitat were obtained by squeezing the tops of Sphagnum clumps (approximately $25 \mathrm{~g}$ ) until no water could be expressed from them by manual pressure. At each sampling event, samples were taken at almost exactly the same spots within each site to avoid small-scale differences in the diatom communities (as reported in e.g. Machová-Černá \& Neustupa, 2009). Samples were immediately preserved in Lugol's solution in the field to prevent changes to the species ratio in each community, which could have been caused by sudden changes to the ambient conditions. In total, 84 samples were collected. Epipelon samples were collected during all eight sampling events (48 samples; eight sampling events at six sites). Periphyton samples were not collected during the first two samplings, so only 36 samples (six sampling events at six sites) were obtained (see also Supplementary Table 1, see doi/10.7872/crya/v38.iss3.2017.Suppl.Mat.).

Community structure was based on the relative abundances of diatom species in the samples. Diatoms were counted using permanent slides, which were made according to the standard method of annealing over a gas burner flame (Battarbee et al., 2001) and subsequent mounting into Naphrax medium (Brunel Microscopes Ltd. Wiltshire, UK). From each sample, 300 randomly encountered diatom cells were identified to the species level using an Olympus CX 31 light microscope at $1000 \times$ magnification and standard taxonomic monographs: Krammer \& Lange-Bertalot (1986, 1988, 1991a, 1991b), Krammer (2000, 2002, 2003), LangeBertalot \& Metzeltin (1996), Lange-Bertalot (2001), Lange-Bertalot et al. (2011). Up to 10 cells were counted for diatom colonies that occasionally occurred in the samples.

\section{Statistical analyses}

The original species data were initially tested for the influence of rare and less common species. The first dataset included a complete set of all 300 identified cells from each sample (hereafter referred to as the complete dataset). In the second dataset, all rare diatom species, that did not reach greater than $1 \%$ abundance in any of the samples, were excluded. The third dataset was comprised of the top $25 \%$ of the most common species in the complete dataset. As suggested by Heino \& Soininen (2010) and subsequently supported by Neustupa et al. (2012), this approach should be sufficient to reveal ecological patterns in aquatic communities. The degree of dataset concordance was estimated with the Procrustes statistics (PROTEST; PeresNeto \& Jackson (2001), for an explanation see also Neustupa et al. (2012) and Mutinova et al. (2016)) using 9999 permutations. The compared distance matrices were based on the two-dimensional non-metric multidimensional scaling (NMDS; Kruskal, 1964) using the Bray-Curtis index (Bray \& Curtis, 1957). Pair-wise comparisons revealed that there were no significant differences between datasets, so the first complete dataset was used for subsequent statistical analyses. Statistical analyses were conducted using PAST version 3 software (Hammer et al., 2001) and the vegan package (Oksanen et al., 2012) in $\mathrm{R}$ version 2.15 .1 software (R Development Core Team, 2012).

Regarding large-scale processes, factors were separated into three groups. Time-series and seasons were merged into the time factor group. Geographical 
distances (hereafter referred to as GPS; included sampling site information) and microhabitat type were merged into the space factor group. The geographic distances were obtained from GPS coordinates by creating a similarity matrix that was used for principle coordinates analyses (PCoA) using PAST. The scores from the first $12 \mathrm{PCoA}$ axes were used as a space variable. The $\mathrm{pH}$, conductivity, and mean temperature factors were standardized and then merged into the environment factor group.

The complete species dataset was Hellinger-transformed (Legendre \& Gallagher, 2001). The quantification of joint and pure effects of factor groups on the diatom community structure was performed in $\mathrm{R}$ ( $\mathrm{R}$ Development Core Team, 2012) with a permutational multivariate analysis of variance using the Bray-Curtis similarity index and 9999 permutations (permutational MANOVA; Anderson, 2001). Factor effects were sequentially estimated in the model. For example, when environment, space, and time were on the first, second, and third rows, respectively, the first row quantified the pure effect of environment plus the joint effects of environment with other two factors. The second row included the pure effect of space plus the joint effects of space and time, minus the effect of environment. The last row estimated the pure effect of time after the effects of the other two factors were subtracted.

To investigate variation in the diatom community in detail at a large scale, similar models of permutational MANOVA analyses were conducted using individual variables (only those variables that were found to have significant effects in the preceding analysis were considered, Table 2). The same approach was used to investigate small-scale processes within single sites. The complete dataset was divided into six sub-datasets corresponding to the individual sampling sites, and only the microhabitat type was included in the analysis as a spatial factor. It is important to note that the resulting $\mathrm{R}^{2}$ values are highly dependent on the number of samples in the dataset and the degrees of freedom associated with each factor. Therefore, $\mathrm{R}^{2}$ values are not comparable between different permutational MANOVA models. Thus, we also provided adjusted $\mathrm{R}^{2}$ values, which are comparable with each other in all cases, and we refer always to adjusted $\mathrm{R}^{2}$ values below.

Table 2. Partitioning of variation in the diatom community structure at the large scale (i.e., within sites) by permutational MANOVA tests using the Bray-Curtis similarity index and 9999 permutations. The analysis considered (A) time, space, and environment factor groups and (B) individual GPS, microhabitat, $\mathrm{pH}$, conductivity, and temperature factors. In each case, only the pure effect is shown. Complete results of individual permutational MANOVA tests are listed in Supplementary Tables 4 and 5. ${ }^{* * *} \mathrm{P}<0.001,{ }^{* *} \mathrm{P}<0.01,{ }^{*} \mathrm{P}<0.05$, n.s. $\mathrm{P}>0.05$

\begin{tabular}{llrccccc}
\hline & & $d f$ & Sums of squares & F ratio & $R^{2}$ & Adjusted $R^{2}$ & $P$ value \\
\hline A & time & 6 & 1.083 & 1.237 & 0.040 & 0 & n.s. \\
& space & 13 & 10.019 & 5.284 & 0.371 & 0.254 & $* * *$ \\
& environment & 2 & 0.825 & 2.829 & 0.031 & 0.007 & $* *$ \\
& residuals & 61 & 8.897 & - & 0.330 & - & - \\
B & GPS & 12 & 9.813 & 5.490 & 0.363 & 0.256 & $* * *$ \\
& microhabitat & 1 & 0.321 & 2.156 & 0.012 & 0.000 & n.s. \\
& temperature & 1 & 0.065 & 0.436 & 0.002 & 0 & n.s. \\
& conductivity & 1 & 0.585 & 3.924 & 0.022 & 0.010 & $* *$ \\
pH & 1 & 0.147 & 0.985 & 0.005 & 0 & n.s. \\
& residuals & 67 & 9.979 & - & 0.370 & - & - \\
\hline
\end{tabular}


Two-dimensional NMDS diagrams (Kruskal, 1964; Clarke, 1993), allowed for visualization of the effects of season, site, or microhabitat on diatom communities, were constructed in PAST using the Bray-Curtis similarity index. We also examined diversity indices, particularly species richness, and the Shannon diversity index. These indices were calculated for every sample using the complete dataset (Supplementary Table 2, see doi/10.7872/crya/v38.iss3.2017.Suppl.Mat.), and were subsequently divided into the following groups of variables: time-series, season, site, and microhabitat. The Mann-Whitney test (Mann \& Whitney, 1947) was used to compare the two microhabitat types. In all other cases, the Kruskal-Wallis test (Kruskal, 1964), with post-hoc Mann-Whitney pair-wise comparisons using the Bonferroni correction, was performed. Boxplots were created to illustrate differences in the diversity indices of individual groups. Lastly, the relationships between diversity indices and particular environmental factors ( $\mathrm{pH}$ and conductivity) were tested using ordinary least square regression and were illustrated with biplots.

\section{RESULTS}

In total, 73 diatom species, belonging to 31 genera, were identified in 84 samples (Supplementary Table 3, see doi/10.7872/crya/v38.iss3.2017.Suppl.Mat.). The species richness per sample ranged from 2 to 26, and mean species richness was 11.3 with a standard deviation of 5.0. Species richness values that were recorded during individual seasons and at individual sites are given in Table 1 and Supplementary Table 1 (see doi/10.7872/crya/v38.iss3.2017.Suppl.Mat.). The top $25 \%$ of the most abundant species are as follows in descending order: Frustulia saxonica Rabenhorst, Eunotia bilunaris (Ehrenberg) Schaarschmidt, Brachysira serians (Brébisson) Round \& D.G. Mann, Eunotia paludosa Grunow, Encyonopsis cf. delicatissima (Hustedt) Krammer, Eunotia cf. arcubus Nörpel \& Lange-Bertalot, Achnanthidium minutissimum (Kützing) Czarnecki, Brachysira neoexilis LangeBertalot, Brachysira cf. neoexilis Lange-Bertalot, Eunotia exigua (Brébisson ex Kützing) Rabenhorst, Pinnularia rhombarea Krammer, Pinnularia pseudogibba Krammer, Cymbella falaisensis (Grunow) Krammer \& Lange-Bertalot, Kobayasiella sp., Eunotia glacialis Meister, Pinnularia macilenta Ehrenberg, Tabellaria flocculosa (Roth) Kützing, Fragilaria construens (Ehrenberg) Grunow, Nitzschia sp. 1.

Variation partitioning of pure and joint factor effectsrs by permutational MANOVA, showed strong spatial structuring of diatom communities at both scales (Tables 2, 3). At the large scale (i.e., differences among all six sites), the pure effect of space accounted for $25 \%(\mathrm{P}<0.001)$ of the total variation in the diatom community structure (Table 2). The fraction of variance explained by the environment decreased from $22.7 \%(\mathrm{P}<0.001)$ to $0.7 \%(\mathrm{P}<0.01)$ after space and time were included in the model (Supplementary Table 4). Both the NMDS ordination plot (similarity among diatom communities, Fig. 2) and scatter plot ( $\mathrm{pH}$ versus conductivity values, Fig. 1) revealed clear differences among localities. Temporal changes within sites were not significant at the large scale (Table 2 and Supplementary Table 4 (doi/10.7872/crya/v38.iss3.2017.Suppl.Mat.)). Moreover, high covariation of geographic position with environmental factors was observed at the large scale (Supplementary Tables 4, 5), and covariation of temporal changes with environmental factors was seen at the small scale (Table 3). For example, sites 1 and 2 were characterized by relatively high $\mathrm{pH}$ and conductivity, whereas site 6 had the lowest 
Table 3. Partitioning of variation in the diatom community structure at the small scale (i.e., within sites) by permutational MANOVA tests using the Bray-Curtis similarity index and 9999 permutations. In each case, only the pure effect is shown. The analyses accounting for microhabitat, time, and environment factors were conducted for all six sites. The pure effect of the environment was imperceptible, so it was excluded from the table. For site 1, tests considering the individual variables microhabitat, time-series, and season were conducted. ${ }^{* * *} \mathrm{P}<0.001$, ** $\mathrm{P}<0.01, * \mathrm{P}<0.05$, n.s. $\mathrm{P}>0.05$

\begin{tabular}{|c|c|c|c|c|c|c|c|}
\hline & & $d f$ & Sums of squares & $F$ ratio & $R^{2}$ & Adjusted $R^{2}$ & $P$ value \\
\hline \multirow[t]{3}{*}{ site 1} & time & 4 & 0.195 & 2.261 & 0.361 & 0.077 & $* *$ \\
\hline & microhabitat & 1 & 0.124 & 5.740 & 0.049 & 0 & $* * *$ \\
\hline & residuals & 5 & 0.108 & - & 0.200 & - & - \\
\hline \multirow[t]{3}{*}{ site 2} & time & 4 & 0.181 & 1.022 & 0.126 & 0 & n.s. \\
\hline & microhabitat & 1 & 0.780 & 17.577 & 0.541 & 0.503 & $* * *$ \\
\hline & residuals & 5 & 0.222 & - & 0.154 & - & - \\
\hline \multirow[t]{3}{*}{ site 3} & time & 4 & 0.154 & 1.140 & 0.164 & 0 & n.s. \\
\hline & microhabitat & 1 & 0.491 & 14.551 & 0.522 & 0.483 & $* * *$ \\
\hline & residuals & 5 & 0.169 & - & 0.179 & - & - \\
\hline \multirow[t]{3}{*}{ site 4} & time & 4 & 0.117 & 1.080 & 0.182 & 0 & n.s. \\
\hline & microhabitat & 1 & 0.145 & 5.364 & 0.225 & 0.161 & $* *$ \\
\hline & residuals & 5 & 0.135 & - & 0.210 & - & - \\
\hline \multirow[t]{3}{*}{ site 5} & time & 4 & 0.225 & 1.242 & 0.285 & 0 & n.s. \\
\hline & microhabitat & 1 & 0.105 & 2.324 & 0.133 & 0.061 & n.s. \\
\hline & residuals & 5 & 0.227 & - & 0.286 & - & - \\
\hline \multirow[t]{3}{*}{ site 6} & time & 4 & 0.050 & 1.201 & 0.278 & 0 & n.s. \\
\hline & microhabitat & 1 & 0.049 & 4.726 & 0.273 & 0.213 & * \\
\hline & residuals & 5 & 0.052 & - & 0.289 & - & - \\
\hline
\end{tabular}

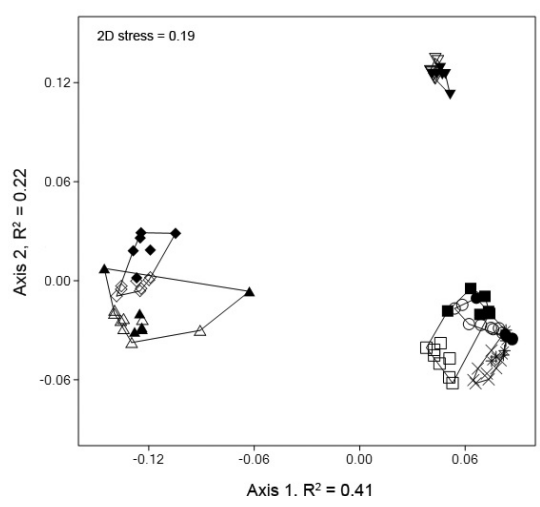

Fig. 2. NMDS ordination plot based on the diatom composition of samples collected at individual sites and individual microhabitats. Triangle $=$ site 1 , diamond $=$ site 2 , square $=$ site 3 , cross $=$ site 4 , circle $=$ site 5 , inverted triangle $=$ site 6 . Empty symbol $=$ epipelon, filled symbol and star $=$ Sphagnum spp. periphyton.

$\mathrm{pH}$ of all sites (Table 1, Fig. 1). A similar separation of sites based on the diatom community is clear in the NMDS graph as well (Fig. 2), even though in this case the separation of site 6 seems more profound than in the illustration based on environmental factors (Fig.1).

We also focused on the effects of individual spatial and environmental variables between sites (Table 2 part B, complete models are given in Supplementary 
Table 5 (doi/10.7872/crya/v38.iss3.2017.Suppl.Mat.)) in subsequent analyses. The detailed inspection of pure and joint effects of individual variables at the large scale indicated that the spatial variability of diatom communities was affected by the geographic positions of sites (represented by GPS coordinates) but not differences between microhabitats (Supplementary Table 5, see doi/10.7872/crya/v38.iss3.2017. Suppl.Mat.; also shown in Fig. 2). Regarding environmental factors, only conductivity was found to have a significant effect on diatom community structure after the effects of other variables were removed from the model.

A significant effect of the pure effect of microhabitat was revealed in the analysis of variation at a small scale (i.e., within sites; Table 3). Microhabitat type played a significant role in shaping diatom communities at five of the six sites, whereas the effect of time was mostly insignificant (Table 3). As expected, the pure effects of both environment and time were imperceptible at the small scale. Temporal changes were not important at the large scale, and environmental variability mainly represented temperature values. In the case of site 1 only, there was as much as $7.7 \%$ of variation in the diatom community structure that was significantly explained by time $(\mathrm{P}<0.01)$. Regarding all models that considered both the small and large scale, the fraction of unexplained variability, ranged from $15.4 \%$ to $37 \%\left(\mathrm{R}^{2}\right.$ values of residuals; Tables 2 and 3 ).

Comparisons of diversity indices (species richness and Shannon diversity index) revealed that there were no detectable differences associated with temporal changes (including both time-series and season), but the effect of space on species diversity was clear at both the large (Fig. 3) and small scales (Kruskal-Wallis tests, $\mathrm{P}<0.001$ at both scales). Post-hoc Mann-Whitney pair-wise comparisons using Bonferroni corrections indicated that sites could be generally divided into three groups with more or less similar species richness and Shannon diversity index values (also shown in Fig. 3):

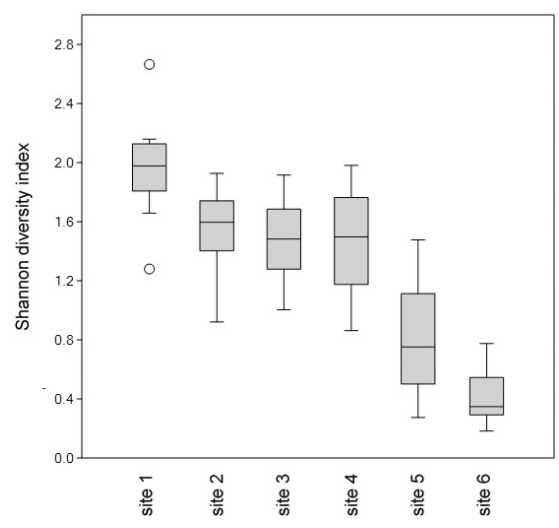

Fig. 3. Box plots illustrating differences in Shannon diversity indices of diatom communities among individual sites.
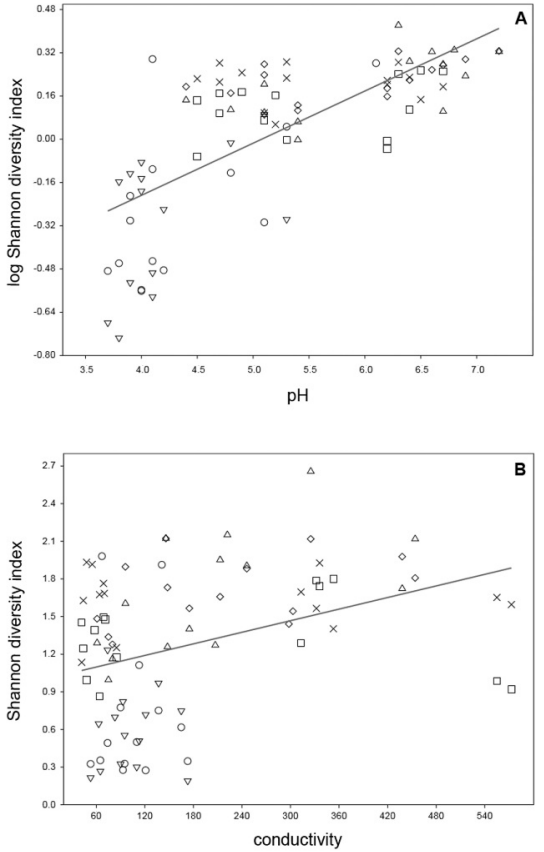

Fig. 4. Illustration of ordinary least square regression of Shannon diversity index depending on (A) $\mathrm{pH}$ and (B) conductivity. The individual sites are shown using the same symbols as in the ordinations. Triangle $=$ site 1 , diamond $=$ site 2 , square $=$ site 3, cross $=$ site 4 , circle $=$ site 5 , inverted triangle $=$ site 6 . 
(1) site 1 which was characterized by high diversity index values; (2) sites 2, 3, and 4 with intermediate values; and (3) sites 5 and 6 with low values. Differences in diversity between sites were associated with variability of the measured environmental factors. Species richness and the Shannon diversity index (Fig. 4) were positively correlated with both $\mathrm{pH}\left(\mathrm{r}=0.7 / 0.7, \mathrm{R}^{2}=0.49 / 0.5, \mathrm{P}<0.001\right)$ and conductivity $\left(\mathrm{r}=0.38 / 0.4, \mathrm{R}^{2}=0.15 / 0.1, \mathrm{P}<0.001\right)$. Microhabitat type seemed to be an unimportant factor for diatom diversity at the large scale, but significant differences were revealed within the three sampling sites. In particular, species richness differed remarkably between sites 4 and 5, and the Shannon diversity indices differed at sites 3 and 4 (Mann-Whitney tests, $\mathrm{P}<0.05$ at all sites).

\section{DISCUSSION}

Distinct temporal dynamics of diatoms in peatland microhabitats were not found in this study. While this result is in agreement with the studies of Nováková (2007) and Svoboda et al. (2014), it does not support the findings of Machová-Černá \& Neustupa (2009) and Neustupa et al. (2012), which detected noticeable changes in peatland microphytobenthos that were likely caused by freezing during the winter. The time factor group (both time-series and season) was essentially reflected in the temporal changes of environmental factors (as has been documented by Tahvanainen et al., 2003). In our study, seasonal changes were detectable by the temperature. Two other investigated environmental factors, $\mathrm{pH}$ and conductivity, were not radically altered at a single site over time. We assumed that the lack of significant temporal dynamics in diatom communities detected at site 1 were due to the location of the site, which was very close to Mácha Lake. The temporal changes in the diatom communities and environmental conditions of Mácha Lake (Neustupa et al., 2011) might affect both the species pool and environmental conditions at adjacent sites.

Consistent with our results, recent studies have demonstrated a significant effect of spatial distance on the structure of freshwater microphytobenthic communities (Potapova \& Charles, 2002; Poulíčková et al., 2004; Soininen, 2004; Pals et al., 2006; Machová-Černá \& Neustupa, 2009; Veselá, 2009; Heino et al., 2010; Neustupa et al., 2012, 2013; Svoboda et al., 2014; Mutinová et al., 2016). In our study, spatial variation was associated with the variability of measured environmental factors ( $\mathrm{pH}$ and conductivity), microhabitat type (periphyton or epipelon), and undetermined site-specific factors. The unknown spatial factors might incorporate the history of the site as well as any unmeasured abiotic factors (e.g., nitrogen, phosphorus and silicate, as well as light intensity) and biotic interactions (e.g., predation, competition and mutualism) with a spatial distribution (Borcard et al., 1992; Anderson \& Gribble, 1998). The spatial heterogeneity of diatoms is evident at the large scale, and it may conceal the effects of factors with small-scale distributions (as shown in Soininen, 2004; Pals et al., 2006; Mutinová et al., 2016). Therefore, the significance of the effect of individual environmental and spatial factors might depend on the spatial scale that is being investigated. Our study showed that the community structure of diatoms within localities differed between Sphagnum periphyton and epipelon microhabitats but were not significantly different at the large scale. Total species richness and Shannon diversity indices were similar between the two microhabitats. We suggest that although the characteristics of those microhabitats differ (e.g., living vs. inert substrates), both Sphagnum periphyton and 
epipelon have similar potential to support rich diatom communities. Lim et al. (2001) and Soininen \& Eloranta (2004) claimed that diatom communities in sediments should exhibit high species diversity because the sediment usually contains sets of diatoms from adjacent microhabitats and empty frustules. Sphagnum periphyton is a complex and biologically active habitat, so it supports a highly diverse community of microorganisms (Soininen \& Eloranta, 2004; Taniguchi \& Tokeshi, 2004; Townsend \& Gell, 2005). However, our study did not focus on specific microhabitat details, so it is not possible to assess whether small-scale differences between diatom communities represent the effect of specific substrates or the spatial heterogeneity of ecologically neutral substrates.

Future diatom ecology research could be improved by progressively increasing the sensitivity of measurements of environmental variability in space and time (as in Tahvanainen et al., 2003). We propose that studies based on traditional diatom morphospecies are relevant to our understanding of the ecology and community dynamics of freshwater microphytobenthos within a particular geographic area (e.g. Dixit et al., 1992; Coesel, 2001, 2003; Poulíčková et al., 2004; Charles et al., 2006) because the large factor gradients (e.g., differences among sites) are detectable using traditionally defined species (Mitchell et al., 2014). However, small-scale and temporal community dynamics should be addressed using manipulated in situ experiments (Shurin, 2000) and/or by advanced morphological or molecular approaches (e.g., Lara et al., 2011, Lew et al., 2015) that provide higher taxonomic resolution to achieve more accurate diversity assessments (Heger et al., 2009, Mitchell et al., 2014). It was recently shown that some traditional diatom morphospecies represent different genetic and morphological entities that differ in their ecological preferences (Creach et al. 2006; Potapova \& Hamilton 2007; Vanelslander et al. 2009; Veselá et al. 2012; Kulichová \& Fialová 2016). In our study, several species complexes, which have been examined using a polyphasic approach, often occurred in high abundances: Achnanthidium minutissimum (Kützing) Czarnecki (Potapova \& Hamilton, 2007; Pinseel et al., 2017), Eunotia bilunaris (Ehrenberg) Schaarschmidt (Vanormelingen et al., 2007), Frustulia crassinervia-saxonica (Veselá et al., 2012; Kulichová \& Fialová, 2016), Gomphonema parvulum (Kützing) Kützing (Kermarrec et al., 2013), Nitzschia palea (Kützing) W.Smith (Trobajo et al., 2009), and Sellaphora spp. (Mann et al., 2004; Poulíčková et al., 2008). It is probable that if hidden diversity within traditional diatom species had been taken into account, the differences between microhabitats and/or seasons would have become clearer. Diatom species complexes have the potential to be used as reliable indicators for small-scale and temporal patterns. However, it is questionable whether variability in species complexes will exhibit a general trend or whether particular species complexes will respond specifically to environmental conditions.

Acknowledgements. We would like to thank Jiří Neustupa for his initial help with our research and statistical analysis. This study was supported by the project partnership in the framework of Programme CZ07 - EEA Scholarship Programme; Bilateral Scholarship Programme number NF-CZ07-ICP-3-193-2015.

\section{REFERENCES}

ANDERSON M. \& GRIBBLE N., 1998 - Partitioning the variation among spatial, temporal and environmental components in a multivariate data set. Australian journal of ecology 23: 158-167.

ANDERSON M., 2001 - A new method for non-parametric multivariate analysis of variance. Austral ecology 26: 32-46. 
BATTARBEE R.W., JONES V.J., FLOWER R.J., CAMERON N.G., BENNION H., CARVALHO L. \& JUGGINS S., 2001 - Diatoms. In: Smol J.P., Birks H.J.B. \& Last W.M. (eds), Tracking environmental change using lake sediments, vol. 3: Terrestrial, algal, and siliceous indicators. Dordrecht, The Netherlands, Kluwer Academic Publishers, pp. 155-202.

BORCARD D., LEGENDRE P. \& DRAPEAU P., 1992 - Partialling out the spatial component of ecological variation. Ecology 73: 1045-1055.

BORICS G., TÓTHMÉRÉSZ B., GRIGORSZKY I., PADISÁK J., VÁRBÍRÓ G. \& SZABÓ S., 2003 - Algal assemblage types of bog-lakes in Hungary and their relation to water chemistry, hydrological conditions and habitat diversity. Hydrobiologia 502: 145-155.

BRAY J.R. \& CURTIS J., 1957 - An ordination of the upland forest communities of southern Wisconsin. Ecological monographs 27: 325-249.

CABIN R.J. \& MITCHELL R.J., 2000 - To Bonferroni or not to Bonferroni: When and how are the questions. Bulletin of the ecological society of America 81: 246-248.

CHARLES D.F., ACKER F.W., HART D.D., REIMER C.W. \& COTTER P.B., 2006 — Large-scale regional variation in diatom-water chemistry relationships: rivers of the eastern United States. Hydrobiologia 561: 27-57.

CLARKE K. R., 1993 - Non-parametric multivariate analyses of changes in community structure. Australian journal of ecology 18: 117-143.

COESEL P. F., 2001 - A method for quantifying conservation value in lentic freshwater habitats using desmids as indicator organisms. Biodiversity and conservation 10: 177-187.

COESEL P. F., 2003 - Desmid flora data as a tool in conservation management of Dutch freshwater wetlands. Biologia 58: 717-722.

DIXIT S., SMOL J., KINGSTON J. \& CHARLES D., 1992 - Diatoms: Powerful indicators of environmental change. Environmental science \& technology 26: 23-33.

FRÁNKOVÁ M., BOJKOVÁ J., POULÍČKOVÁ A. \& HÁJEK M., 2009 — The structure and species richness of the diatom assemblages of the Western Carpathian spring fens along the gradient of mineral richness. Fottea 9: 355-368.

GILBERT D., AMBLARD C., BOURDIER G. \& FRANCEZ A.-J., 1998a — Short-term effect of nitrogen enrichment on the microbial communities of a peatland. Hydrobiologia 373/374: 111-119.

GILBERT D., AMBLARD C., BOURDIER G. \& FRANCEZ A.-J., 1998b - The microbial loop at the surface of a peatland: Structure, function, and impact of nutrient input. Microbial ecology 35: 83-93.

HAMMER Ø., HARPER D.A.T. \& RYAN P.D., 2001 — PAST: Paleontological statistics software package for education and data analysis. Palaeontologia electronica 4: 9. http://palaeoelectronica.org/2001_1/past/issue1_01.htm. Accessed 14 October 2016.

HEGER T.J., MITCHELL E.A.D., LEDEGAN̄CK P., VINCKE S., VAN DE VIJVER B. \& BEYENS I., 2009 - The curse of taxonomic uncertainty in biogeograhical studies of free-living terrestrial prostist: A case study of testate amoebae from Amsterdam Island. Journal of biogeography 39: 1551-1560.

HEINO J., BINI L.M., KARJALAINEN S.M., MYKRÄ H., SOININEN J., VIEIRA L.C.G. \& DINIZFILHO J.A.F., 2010 - Geographical patterns of micro-organismal community structure: Are diatoms ubiquitously distributed across boreal streams? Oikos 119: 129-137.

HEINO J. \& SOININEN J., 2010 - Are common species sufficient in describing turnover in aquatic metacommunities along environmental and spatial gradients? Limnology and oceanography 55: 2397-2402.

KELly M.G., GÓMEZ-RODRÍGUEZ C., KAHLERT M., ALMEIDA S.F.P., BENNETT C., BOTTIN M., DELMAS F., DESCY J.P., DÖRFLINGER G., KENNEDY B., MARVAN P., OPATRILOVA L., PARDO I., PFISTER P., ROSEBERY J., SCHNEIDER S. \& VILBASTE S., 2012 - Establishing expectations for pan-European diatom based ecological status assessments. Ecological indicators 20: 177-186

KRAMMER K. \& LANGE-BERTALOT H., 1986 - Bacillariophyceae, 1. Teil. In: Ettl H., Gerloff J., Heynig H. \& Mollenhauer D. (eds), Süsswasserflora von Mitteleuropa 2/1. Jena, G. Fischer Verlag.

KRAMMER K. \& LANGE-BERTALOT H., 1988 - Bacillariophyceae, 2. Teil. In: Ettl H., Gerloff J., Heynig H. \& Mollenhauer D. (eds), Süsswasserflora von Mitteleuropa 2/1. Jena, G. Fischer Verlag.

KRAMMER K. \& LANGE-BERTALOT H., 1991a - Bacillariophyceae, 3. Teil. In: Ettl H., Gerloff J., Heynig H. \& Mollenhauer D. (eds), Süsswasserflora von Mitteleuropa 2/1. Jena, G. Fischer Verlag. 
KRAMMER K. \& LANGE-BERTALOT H., 1991b - Bacillariophyceae, 4. Teil. In: Ettl H., Gerloff J., Heynig H. \& Mollenhauer D. (ed.), Süsswasserflora von Mitteleuropa 2/1. Jena, G. Fischer Verlag.

KRAMMER K., 2000 - Diatoms of Europe, vol. 1: The genus Pinnularia. In: Lange-Bertalot H. (ed.), Diatoms of the European inland water and comparable habitats. Ruggell, A.R.G. Gantner Verlag K.G.

KRAMMER K., 2002 - Diatoms of Europe, vol. 3: Cymbella. In: Lange-Bertalot H. (ed.), Diatoms of the European inland water and comparable habitats. A.R.G. Gantner Verlag K.G.

KRAMMER K., 2003 - Diatoms of Europe, vol. 4: Cymbopleura, Delicata, Navicymbula, Gomphocymbellopsis, Afrocymbella. In: Lange-Bertalot H. (ed.), Diatoms of the European inland water and comparable habitats. A.R.G. Gantner Verlag K.G.

KERMARREC L., BOUCHEZ A., RIMET F. \& HUMBERT J.-F., 2013 - First evidence of the existence of semi-cryptic species and of a phylogeographic structure in the Gomphonema parvulum (Kützing) Kützing complex (Bacillariophyta). Protist 164: 686-705.

KRUSKAL J.B., 1964 - Multidimensional scaling by optimizing goodness of fit to a nonmetric hypothesis. Psychometrika 29: 1-27.

KULICHOVÁ J. \& FIALOVÁ M., 2016 - Correspondence between morphology and ecology: Morphological variation of the Frustulia crassinervia-saxonica species complex (Bacillariophyta) reflects the ombro-minerotrophic gradient. Cryptogamie, Algologie 37: 15-28.

LAMENTOWICZ M. \& MITCHELL E.A.D., 2005 - The ecology of testate amoebae (protists) in Sphagnum in north-western Poland in relation to peatland ecology. Microbial ecology 50: 48-63.

LANGE-BERTALOT H. \& METZELTIN D., 1996 — Iconographia Diatomologica, vol. 2: Indicators of oligotrophy. 800 taxa representative of three ecologically distinct lake types: Carbonate buffered, oligodystrophic, weakly buffered soft water. Königstein, Koeltz Scientific Books,.

LANGE-BERTALOT H., 2001 - Diatoms of Europe, vol. 2: Navicula sensu stricto, 10 genera separated from Navicula sensu lato, Frustulia. In: Lange-Bertalot H. (ed.), Diatoms of the European inland water and comparable habitats. Ruggell, A.R.G. Gantner Verlag K.G.

LANGE-BERTALOT H., BĄK M., WITKOWSKI A. \& TAGLIAVENTI N., 2011 - Diatoms of Europe, vol. 6: Eunotia and some related taxa. In: Lange-Bertalot H. (ed.), Diatoms of the European inland water and comparable habitats. A.R.G. Gantner Verlag K.G.

LARA E., MITCHELL E.A.D., MOREIRA D. \& LÓPEZ GARCÍA P., 2011 — Highly diverse and seasonally dynamic protist community in a pristine peat bog. Protist 162: 14-32.

LEGENDRE P. \& GALLAGHER E.D., 2001 - Ecologically meaningful transformations for ordination of species data. Oecologia 129: 271-280.

LEGENDRE P., BORCARD D. \& PERES-NETO P.R., 2005 - Analyzing beta diversity: Partitioning the spatial variation of community composition data. Ecological monographs 75: 435-450.

LEIBOLD M.A., HOLYOAK M., MOUQUET N., AMARASEKARE P., CHASE J.M., HOOPES M.F., HOLT R.D., SHURIN J.B., LAW R., TILMAN D., LOREAU M. \& GONZALEZ A., 2004 - The metacommunity concept: A framework for multi-scale community ecology. Ecology letters 7: 601-613.

LEW S., KOBLÍŽEK M., LEW M., MEDOVÁ H., GLIŃSKA-LEWCZUK K. \& OWSIANNY M.P., 2015 - Seasonal changes of microbial communities in two shallow peat bog lakes. Folia microbiologica 60: 165-175.

LIM D., KWAN C. \& DOUGLAS M., 2001 - Periphytic diatom assemblages from Bathurst Island, Nunavut, Canadian High Arctic: An examination of community relationships and habitat preferences. Journal of phycology 37: 379-392.

MACHOVÁ-ČERNÁ K. \& NEUSTUPA J., 2009 - Spatial distribution of algal assemblages in a temperate lowland peat bog. International review of hydrobiology 94: 40-56.

MANN D.G., MCDONALD S.M., BAYER M.M., DROOP S.J.M., CHEPURNOV V.A., LOKE R.E., CIOVANU A. \& DU BUF J.M.H., 2004 - The Sellaphora pupula species complex (Bacillariophyceae): Morphometric analysis, ultrastructure and mating data provide evodence for five new species. Phycologia 43: 459-482.

MANN H.B. \& WHITNEY D.R., 1947 - On a test of whether one of two random variables is stochastically larger than the other. The Annals of mathematical statistics 8: 50-60.

MATALONI G., 1999 - Ecological studies on algal communities from Tierra del Fuego peat bogs. Hydrobiologia 391: 157-171.

MIECZAN T., 2007 - Seasonal patterns of testate amoebae and ciliates in three peatbogs: Relationship to bacteria and flagellates (Poleski National Park, Eastern Poland). Ecohydrology and hydrobiology 7: 295-305. 
MIECZAN T., 2009 - Ecology of testate amoebae (Prostists) in Sphragnum peatlands of eastern Poland: Vertical micro-distribution and species assemblages in relation to environmental parameters. Annales de limnologie - International journal of limnology 45: 41-49.

MITCHELL E.A.D., GILBERT D., BUTTLER A., AMBLARD C., GROSVERNIER P. \& GOBAT J.-M., 2003 - Structure of microbial communities in Sphagnum peatlands and effect of atmospheric carbon dioxide enrichment. Microbial ecology 46: 187-199.

MITCHELL E.A.D., CHARMAN D.J. \& WARNER B.G., 2008 - Testate amoebae analysis in ecological and paleoecological studies of wetlands: Past, present and future. Biodiversity and conservation 17: 2115-2137.

MITCHELL E.A.D., LAMENTOWICZ M., PAYNE R.J. \& MAZEI Y., 2014 — Effect of taxonomic resolution on ecological and palaeoecological inference: A test using testate amoeba water table depth transfer functions. Quarternary science reviews 91: 62-69.

MUTINOVÁ P.T., NEUSTUPA J., BEVILACQUA S. \& TERLIZZI A., 2016 - Host specificity of epiphytic diatom (Bacillariophyceae) and desmid (Desmidiales) communities. Aquatic ecology 50: 697-709.

NEUSTUPA J., ČERNÁ K. \& ŠŤASTNÝ J., 2011 — The effects of aperiodic desiccation on the diversity of benthic desmid assemblages in a lowland peat bog. Biodiversity and conservation 20: 1695-1711.

NEUSTUPA J., ČERNÁ K. \& ŠŤASTNÝ J., 2012 — Spatio-temporal community structure of peat bog benthic desmids on a microscale. Aquatic ecology 46: 229-239.

NEUSTUPA J., VESELÁ J. \& ŠŤASTNÝ J., 2013 — Differential cell size structure of desmids and diatoms in the phytobenthos of peatlands. Hydrobiologia 709: 159-171.

NOVÁKOVÁ S., 2007 - Structure and dynamics of the algal flora in subalpine mires in the Krkonoše Mountains (Giant Mountains; Czech Republic). Nova Hedwigia 84: 441-458.

OKSANEN J., BLANCHET F.G., KINDT R., LEGENDRE P., MINCHIN P.R., O'HARA R.B., SIMPSON G.L., SOLYMOS P., STEVENS M.H.H. \& WAGNER H., 2013 — vegan: community ecology package. $\mathrm{R}$ package version 2.4-0. http://CRAN.R-project.org/ package=vegan. Accessed 14 October 2016.

PALS A., ELST D., MUYLAERT K. \& VAN ASSCHE J., 2006 - Substrate specificity of periphytic desmids in shallow softwater lakes in Belgium. Hydrobiologia 568: 159-168.

PERES-NETO P.R. \& JACKSON D.A., 2001 - How well do multivariate data sets match? The advantages of a Procrustean superimposition approach over the Mantel test. Oecologia 129: $169-178$.

PINSEEL E., VANORMELINGEN P., HAMILTON P.B., VYVERMAN W., VAN DE VIJVER B. \& KOPALOVA K., 2017 - Molecular and morphological characterization of the Achnanthidium minutissimum complex (Bacillariophyta) in Petuniabukta (Spitsbergen, High Arctic) including the description of $A$. digitatum sp. nov. European journal of phycology: DOI: $10.1080 / 09670262.2017 .1283540$

POTAPOVA M. \& CHARLES D.F., 2002 - Benthic diatoms in USA rivers: Distributions along spatial and environmental gradients. Journal of biogeography 29: 167-187.

POTAPOVA M. \& CHARLES D.F., 2005 - Choice of substrate in algae-based water-quality assessment. Journal of the North American benthological society 24: 415-427.

POTAPOVA M. \& HAMILTON P.B., 2007 - Morphological and ecological variation within the Achnanthidium minutissimum (Bacillariophyceae) species complex. Journal of phycology 43: 561-575.

POULÍČKOVÁ A., DUCHOSLAV M. \& DOKULIL M., 2004 — Littoral diatom assemblages as bioindicators of lake trophic status: A case study from perialpine lakes in Austria. European journal of phycology 39: 143-152.

POULÍČKOVÁ A., ŠPAČKOVÁ J., KELlY M.G., DUCHOSLAV M. \& MANN D.G., 2008 Ecological variation within Sellaphora species complexes (Bacillariophyceae): Specialists or generalists? Hydrobiologia 614: 373-386.

R DEVELOPMENT CORE TEAM, 2012 - R: A language and environment for statistical computing. R Foundation for Statistical Computing, Vienna, Austria. http://www.R-project.org/. Accessed 14 October 2016.

RICE W. R., 1989 - Alalyzing tables of statistical tests. Evolution 43: 223-225.

SHURIN J. B., 2000 - Dispersal limitation, invasion resistance, and the structure of pond zooplankton communities. Ecology 81: 3074-3086.

SOININEN J., 2004 - Determinants of benthic diatom community structure in boreal streams: The role of environmental and spatial factors at different scales. International Review of hydrobiology 89: 139-150. 
SOININEN J. \& ELORANTA P., 2004 - Seasonal persistence and stability of diatom communities in rivers: are there habitat specific differences? European journal of phycology 39: 153-160.

SOININEN J., PAAVOLA R. \& MUOTKA T., 2004 - Benthic diatom community structure in boreal streams: Distribution patterns along environmental and spatial gradients. Ecography 27: 330-342.

SOMMER U., ADRIAN R., DE SENERPONT DOMIS L., ELSER J.J., GAEDKE U., IBELINGS B., JEPPESEN E., LÜRLING M., MOLINERO J.C., MOOIJ W.M., VAN DONK E. \& WINDER M., 2012 - Beyond the Plankton Ecology Group (PEG) model: Mechanisms driving plankton succession. Annual review of ecology, evolution, and systematics 43: 429-448.

SOMMER U., GLIWICZ Z., LAMPERT W. \& DUNCAN A., 1986 - The PEG-model of seasonal succession of planktonic events in fresh waters. Archiv für Hydrobiologie 106: 433-471.

SVOBODA P., KULICHOVÁ J. \& ŠŤASTNÝ J., 2014 - Spatial and temporal community structure of desmids on a small spatial scale. Hydrobiologia 722: 291-303.

ŠŤASTNÝ J., 2010 - Desmids (Conjugatophyceae, Viridiplantae) from the Czech Republic; New and rare taxa, distribution, ecology. Fottea 10: 1-74.

ŠTĚPÁNKOVÁ J., VAVRUŠKOVÁ J., HAŠLER P., MAZALOVÁ P. \& POULÍČKOVÁ A., 2008 Diversity and ecology of desmids of peat bogs in the Jizerské hory Mts. Biologia 63: 895-900.

TAHVANAINEN T., SALLANTAUS T. \& HEIKKILÄ R., 2003 - Seasonal variation of water chemical gradients in three boreal fens. Annales botanici Fennici 40: 345-355.

TANIGUCHI H. \& TOKESHI M., 2004 - Effects of habitat complexity on benthic assemblages in a variable environment. Freshwater biology 49: 1164-1178.

TOWNSEND S.A. \& GELL P.A., 2005 - The role of substrate type on benthic diatom assemblages in the Daly and Roper Rivers of the Australian wet/dry tropics. Hydrobiologia 548: 101-115.

TROBAJO R., CLAVERO E., CHEPURNOV V.A., SABBE K., MANN D.G., ISHIHARA S. \& COX E.J., 2009 - Morphological, genetic and mating diversity within the widespread bioindicator Nitzschia palea (Bacillariophyceae). Phycologia 48: 443-459.

TROPEA A.E., GINN B.K., CUMMING B.F. \& SMOL J.P., 2007 - Tracking long-term acidification trends in Pockwock Lake (Halifax, Nova Scotia), the water supply for a major eastern Canadian city. Lake and reservoir management 23: 279-286.

VANORMELINGEN P., CHEPURNOV V.A., MANN D.G., COUSIN S. \& VYVERMAN W., 2007 - Congruence of morphological, reproductive and ITS rDNA sequence data in some Australasian Eunotia bilunaris (Bacillariophyta). European journal of phycology 42: 61-79.

VESELÁ J., 2009 - Spatial heterogeneity and ecology of algal communities in an ephemeral sandstone stream in the Bohemian Switzerland National Park, Czech Republic. Nova Hedwigia 88: 531-547.

VESELÁ J., URBÁNKOVÁ P., ČERNÁ K. \& NEUSTUPA J., 2012 - Ecological variation within traditional diatom morphospecies: Diversity of Frustulia rhomboides sensu lato (Bacillariophyceae) in European freshwater habitats. Phycologia 51: 552-561. 